\title{
Storage Proteins and Trypsin Inhibitors of an Underutilized Legume, Mucuna: Variability and Their Stability during Germination
}

\author{
Kempohalli S. Chandrashekharaiah \\ Department of Biotechnology, PES Institute of Technology, Bangalore, India. \\ Email: kschandraks@gmail.com
}

Received March 5 ${ }^{\text {th }}, 2013$; revised April $2^{\text {nd }}, 2013$; accepted April 12 $2^{\text {th }}, 2013$

Copyright (C) 2013 Kempohalli S. Chandrashekharaiah. This is an open access article distributed under the Creative Commons Attribution License, which permits unrestricted use, distribution, and reproduction in any medium, provided the original work is properly cited.

\begin{abstract}
The proteins and trypsin inhibitors were isolated from the seeds of different varieties/accessions of an underutilized legume, Mucuna. The crude protein content of all the germplasms of Mucuna is varied from $15 \%-26 \%$, showed little variation and contain higher crude protein when compared with other Mucuna species reported earlier and the pulse crops commonly consumed in India. The seeds of all the varieties of Mucuna exhibited trypsin inhibitor activity. The trypsin inhibitor activity varied from 11 - 14 TIA/mg of protein. Not much variation was observed in trypsin inhibitory activities in soaked seeds compared to dry seeds. Germination of Mucuna pruriens has been carried out and the change in the protein content and trypsin inhibitors were monitored. The protein content of the endosperm increased up to 72 hrs of germination and then decreased. The trypsin inhibitory activity decreased with increase in germination time. The trypsin inhibitor activity was decreased from $14.81 \mathrm{TIA} / \mathrm{mg}$ to $2.62 \mathrm{TIA} / \mathrm{mg}$ (82\% reduction in the trypsin inhibitor activity) after 144 hrs germination.
\end{abstract}

Keywords: Mucuna Seeds; Proteins; Trypsin Inhibitors; Germination; Variation

\section{Introduction}

The seeds of the plants belonging to the family Leguminosae generally rich in proteins required for human consumption in developing countries. Although legumes are rich in proteins, they have limited utilization because of the presence of various anti-nutritional factors including enzyme inhibitors such as trypsin and chymotrypsin inhibitor. Trypsin inhibitors when ingested in large quantities may disrupts the digestive process and leads to undesirable physiological reactions. The suggested functions of protease inhibitors are including acting as storage proteins, regulation of endogenous proteinases, or acting as protective agents against insects or microbial predators. Germination is an inexpensive and effective technology for improving the quality of legumes by reducing the content of antinutritional factors such as protease inhibitors [1] and decrease in storage proteins and enzyme inhibitors of seed is commonly observed during germination. In part, this decrease may be explained by the physical loss of active inhibitor from the seed into the medium [2]. It is generally assumed that the bulk of this decrease is due to proteolysis of the inhibitor by seed proteinases. A slight decrease in trypsin inhibitor activity during germination was reported from navy beans and soybeans [3,4]. Similarly, a decrease in trypsin inhibitor activity of about $16 \%$ in case of horse gram and $40 \%$ in case of moth bean after $72 \mathrm{hrs}$ of germination was observed [5].

Mucuna is one of the lesser known under utilized legume, grown as a minor food crop by tribal and ethnic groups of Asia and Africa. The immature pods and leaves serve as vegetables, while seeds as condiment and main dish by ethnic groups in Nigeria [6]. The genus Mucuna belongs to the family fabaceae (leguminosae) includes up to 150 species and is annual or perennial legumes of pan tropical distribution. More than 15 varieties/accessions are available in southern India. Mucuna seeds are relatively good source of protein and have a relatively favorable amino acid composition. They contain high amounts of certain minerals, including Ca (calcium), Mg (magnesium) and Fe (iron) [7,8]. Mucuna 
seeds are a promising source of protein and to meet the protein demands in developing countries like India, there is a need to source proteins from under utilized legume, Mucuna. However, Protein digestibility is affected by the presence of protease inhibitors which inhibits the proteolytic enzymes. A high level of trypsin inhibitors in the diet stimulates pancreatic juice secretion and causes pancreatic hypertrophy and poor growth performance in animals [9]. Soaking and germination of the seeds slightly reduces the levels of trypsin inhibitory activity (TIA). Germination has been suggested as an inexpensive and effective technology for improving the quality of legumes by enhancing their digestibility [10], increasing the level of amino acids [11] and reducing the content of antinutritional factors [12].

In the present study, the variability of proteins and trypsin inhibitors of eight varieties of Mucuna seeds and their stability during germination have been studied.

\section{Materials and Methods}

The seeds of different verities/species of Mucuna (Mucuna hirsute, Mucuna cochinensis, Mucuna cochinensis MP9, Mucuna pruriens MP7, Mucuna species NRC, Mucuna species IIHR MP5, Mucuna species IC2199 and Mucuna utilis IC25333) were collected from different parts of Karnataka, Tamilnadu, Kerala and IIHR, Bangalore, Karnataka, India. Bovine pancreatic trypsin, $\alpha-$ chymotrypsin, Casein, $\mathrm{N}$-acetyl-DL-phenylalanine- $\beta$-naphthyl ester (APNE), acrylamide, N,N methylene bis acrylamide were obtained from Sigma Chemical Co. All other chemicals were of analytical grade.

\section{Methods}

\subsection{Preparation of Acetone Powder}

The seeds of eight varieties of Mucuna were soaked in distilled water for 12 hours and germinated for six days under standard conditions. The acetone powder $(10 \%)$ of dry, soaked and germinated seeds of eight varieties of Mucuna were prepared according to the method of [13]. Seeds (10 g) were blended in a blender for 5 min using chilled acetone, then filtered using suction pump under vacuum and dried at $37^{\circ} \mathrm{C}$. A $10 \%$ extracts of the dry, soaked and germinated seeds of 8 varieties of Mucuna were prepared using phosphate buffer $\mathrm{pH} 7.0$ by stirring over a magnetic stirrer for $1.5 \mathrm{hrs}$ at $4^{\circ} \mathrm{C}$. The extract was then centrifuged at $10,000 \mathrm{rpm}$ for $15 \mathrm{~min}$ at $4^{\circ} \mathrm{C}$. The supernatants were collected and used for qualitative and quantitative analysis of proteins and trypsin inhibitory activity.

Protein was estimated according to the method of Lowry et al. (1951) [14]. 0.2 to $1.0 \mathrm{ml}$ aliquots of standard bovine serum albumin $(200 \mu \mathrm{g} / \mathrm{mL})$ was pipette into a series of test tubes and volume was made up to $1.0 \mathrm{~mL}$ in each case. $5 \mathrm{~mL}$ of alkaline copper reagent was added to all the test tube. The test tubes were allowed to stand at room temperature for 10 min followed by the addition of $0.6 \mathrm{~mL}$ of FC reagent. The absorbance was read at 660 $\mathrm{nm}$ after 30 min against reagent blank.

\subsection{Determination Trypsin and Trypsin Inhibitory Activity}

The trypsin activity was determined using casein as the substrate [15]. Forty $\mu$ g of trypsin was taken in $2.0 \mathrm{ml}$ of sodium phosphate buffer, $\mathrm{pH} 7.6$ containing $0.15 \mathrm{M}$ $\mathrm{NaCl}$. The reaction was initiated by the addition of 2.0 $\mathrm{ml}$ of $2 \%$ casein at $37^{\circ} \mathrm{C}$. The reaction was stopped after 20 minutes by the addition of $6 \%$ trichloroacetic acid $(6.0 \mathrm{ml})$ and after standing for $1 \mathrm{hr}$, the suspension was filtered through whatman no. 1 filter paper. Absorbance of the filtrate was measured at $280 \mathrm{~nm}$ using spectrophotometer. One trypsin unit is arbitrarily defined as an increase in absorbance by 0.01 at $280 \mathrm{~nm}$ under conditions of assay. The trypsin inhibitor activity was determined using casein as the substrate [16]. Enzyme solution (40 $\mu \mathrm{g}$ of trypsin was preincubated with known aliquots of the inhibitor extract in a total volume of $2 \mathrm{ml}$ at $37^{\circ} \mathrm{C}$ for $10 \mathrm{~min}$ in $0.01 \mathrm{M}$ sodium phosphate buffer, $\mathrm{pH}$ 7.6, containing $0.15 \mathrm{M} \mathrm{NaCl}$. The residual enzyme activity was determined as described above. Trypsin inhibitory unit is defined as the number of trypsin units inhibited under the assay conditions.

\subsection{Polyacrylamide Gel Electrophoresis}

An anionic disc gel electrophoresis was carried out essentially according to the method of Davis and Ornstein [17]. A discontinuous gel system consisting of $8 \%$ separating gel and $4 \%$ spacer gel was used. The electrophoresis was carried out in cold applying a current of $20-25$ $\mathrm{mA}$ for 4 hours using tris-glycine $(\mathrm{pH}$ 8.3) as electrode buffer and bromophenol blue as marker dye. After the electrophoresis, the proteins were stained with coomassie brilliant blue R-250 for 1 hour and destained using 7\% acetic acid. Visualization of trypsin inhibitor in polyacrylamide gel was performed according to Filho and Moriera [18]. The gel was stained for trypsin inhibitory activity separately by incubating the gel in $100 \mu \mathrm{g}$ tryp$\mathrm{sin} / \mathrm{ml}$ in $0.1 \mathrm{M}$ phosphate buffer, $\mathrm{pH} 7.6$ for $20 \mathrm{~min}$ at $37^{\circ} \mathrm{C}$ and then stained using $0.1 \mathrm{M}$ phosphate buffer $\mathrm{pH}$ 7.6 containing $0.8 \mathrm{mM}$ N-acetyl-DL-phenylalanine- $\beta$ naphthyl ester (APNE) and $0.5 \mathrm{mg}$ Diazo Blue B/ml for 1 $\mathrm{hr}$. The gels were stored in 7\% acetic acid.

\section{Result and Discussion}

The protein content of eight varieties of Mucuna samples 
ranged between 15\% - 26\% (Table 1). Among the different varieties tested, the protein content of Mucuna pruriens and Mucuna utilis IC25333 was higher than that of commonly consumed legumes, such as chick pea ( $\mathrm{Ci}$ cer arietinum), green pea (Pisum sativum), common bean (Phaseolus vulgaris), pigeon pea (Cajanus cajan) and lentil (Lens culinaris) which ranged from $18.5 \%$ to $21.9 \%[19,20]$. The protein content of the Mucuna seeds (Mucuna pruriens and Mucuna utilis IC25333) compared well with that of cowpea (Vigna unguiculata) at 29.3\% and mung bean (Phaseolus aureus) at 26.5\% [21,22]. Pugalenthi et al. [23] reported the protein content of Mucuna bean grown in different locations of the tropics and subtropics between $21.0 \%-30.3 \%$. The variation may be attributed to interaction between genetic make up and the environment.

Seeds of different varieties of Mucuna contain trypsin inhibitor activity (Table 1) and range from 11.24 - 14.81 $\mathrm{TIU} / \mathrm{mg}$ of protein, which is higher than that of $9.32 \mathrm{TIU} /$ mg reported by Mugendi et al. [24]. Trypsin inhibitory activity observed in Mucuna seeds is lower than that of soybean (29.1 - $30.2 \mathrm{mg} / \mathrm{g}$ ) [25] and far higher than levels of $1.7-3.6 \mathrm{mg} / \mathrm{g}$ reported for faba bean [26].

Electrophoretic analysis of trypsin inhibitors revealed the presence of five to seven isoinhibitors in the seeds of different varieties of Mucuna (Figures 1(a) and (b)). The Mucuna hirsute and Mucuna pruriens contained a maximum of seven trypsin isoinhibitors. Analysis of proteins during germination of eight varieties of Mucuna seeds are shown in Table 2. Analysis of protein profile of raw and germinated seeds of different varieties of Mucuna revealed that there is no significant change in the protein content up to 48 hrs of germination. After 72 hrs of germination, among eight varieties, M. utilis, $M$. hirsute and $M$. pruriens showed increase in the protein

Table 1. Protein and protease inhibitor profile of seeds of different varieties of Mucuna.

\begin{tabular}{cccc}
\hline No. & Samples & $\begin{array}{c}\text { Total protein } \\
(\mathrm{mg} / \mathrm{gm})\end{array}$ & $\begin{array}{c}\text { TIA } \\
\text { (TIU/mg) }\end{array}$ \\
\hline 1 & Mucuna hirsute & 206 & 12.46 \\
2 & Mucuna cochinensis & 188 & 13.24 \\
3 & Mucuna utilis IC25333 & 261 & 12.91 \\
4 & Mucuna sps. IIHR MP5 & 162 & 11.46 \\
5 & Mucuna pruriens MP7 & 211 & 14.31 \\
6 & Mucuna cochinensis MP9 & 161 & 12.01 \\
7 & Mucuna sps. NRC & 154 & 12.32 \\
8 & Mucuna pruriens & 251 & 14.81 \\
\hline
\end{tabular}

TIA: trypsin inhibitor activity; TIU: trypsin inhibitor unit.

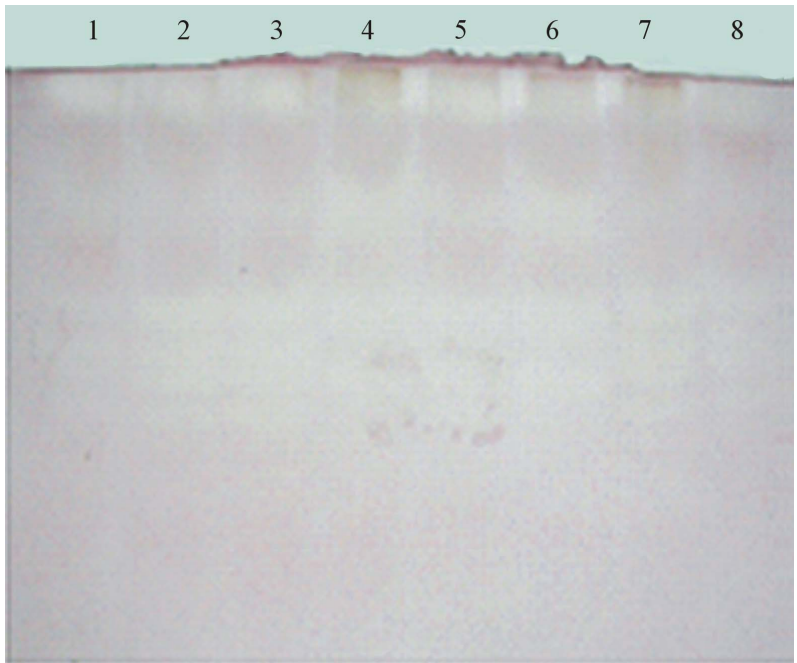

(a)

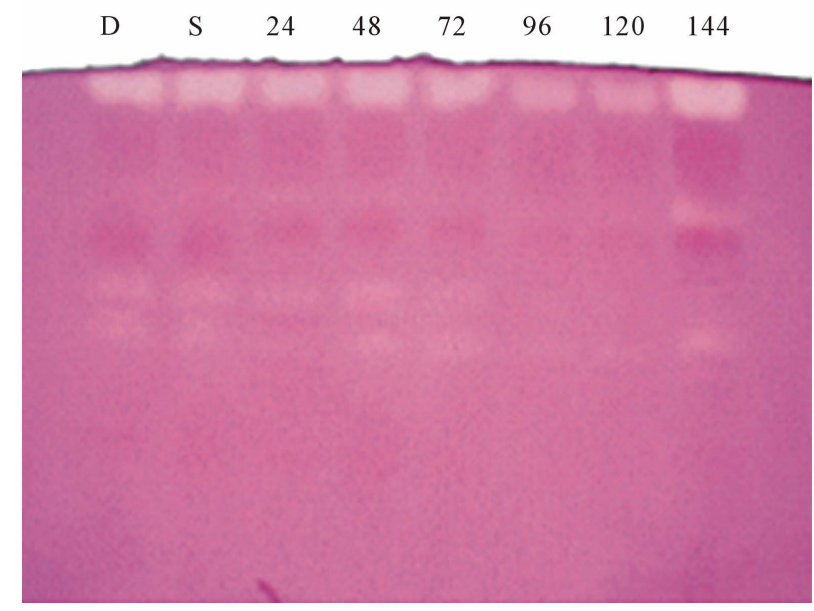

(b)

Figure1. (a) Electrophoretic pattern of trypsin inhibitors isolated from 1) Mucuna hirsute; 2) Mucuna cochinensis; 3) Mucuna utilis IC25333; 4) Mucuna sps. IIHR MP5; 5) Mucuna pruriens MP7; 6) Mucuna cochinensis MP9; 7) $\mathrm{Mu}$ cuna sps. NRC; 8) Mucuna pruriens; (b) Electrophoretic pattern of trypsin inhibitors during germination of seeds of Mucuna pruriens: D: dry; S: soaked, 24 hrs, 48 hrs, 72 hrs, 96 hrs, 120 hrs and 144 hrs of germination.

content by $8.7 \%, 9.4 \%$ and $12.2 \%$ respectively, where as M. cochinensis, $M$. sps. NRC and M. cochinensis MP9 showed increase in the protein content by $19.8 \%, 23 \%$ and $24.5 \%$ respectively. A remarkable increase in the protein content was observed in M. pruriens MP7 (34\%) and $M$. sps. IIHR MP5 (39\%). During 92 hrs of germination, $M$. hirsute, $M$. utilis IC25333, M. pruriens $M P 7, M$. pruriens $M P 9, M$. sps. NRC and M. pruriens showed decrease in the protein content, however, increase in the protein content was observed in $M$. cochinensis (21.4\%) and $M$. sps. IIHR MP5 (45\%). The seeds of all the varieties/species of Mucuna showed decrease and increase in 
Variability and Their Stability during Germination

Table 2. Protein profile of raw and germinated seeds of different varieties/species of Mucuna.

\begin{tabular}{ccccccccc}
\hline Plant material & Dry seeds & Soaked seeds & $24 \mathrm{hrs}$ & $48 \mathrm{hrs}$ & $72 \mathrm{hrs}$ & $96 \mathrm{hrs}$ & $120 \mathrm{hrs}$ & $144 \mathrm{hrs}$ \\
\hline Mucuna hirsute & 203 & 206 & 206 & 213 & 222 & 219 & 158 & 179 \\
Mucuna cochinensis & 182 & 188 & 191 & 208 & 218 & 221 & 114 & 142 \\
Mucuna utilis IC25333 & 254 & 261 & 253 & 272 & 276 & 181 & 108 & 121 \\
Mucuna sps. IIHR MP5 & 151 & 162 & 162 & 178 & 210 & 219 & 144 & 179 \\
Mucuna pruriens MP7 & 206 & 211 & 223 & 240 & 276 & 219 & 132 & 156 \\
Mucuna cochinensis MP9 & 159 & 161 & 174 & 179 & 198 & 119 & 111 & 123 \\
Mucuna sps. NRC & 143 & 154 & 153 & 170 & 176 & 149 & 114 & 164 \\
Mucuna pruriens & 246 & 251 & 253 & 260 & 276 & 219 & 124 & 161 \\
\hline
\end{tabular}

the protein content after 120 and 144 hrs of germination. The observed changes in soluble protein content indicated that these were intimately involved in the process of germination.

The electrophoretic protein band pattern obtained for different varieties of Mucuna are shown in Figure 2(a). The proteins were numbered from anodic end. The protein banding pattern revealed the presence of total 11 bands on anionic polyacrylamide gel electrophoresis. Mucuna cochinensis and Mucuna cochinensis MP9 were identical in both number of bands (total of 09 bands) and banding pattern. Mucuna species NRC and Mucuna species IC2199 were identical in both number of bands (total of 10 bands) and banding pattern. The intensity of bands 4, 5, 7, 8 and 9 of Mucuna species $I C 2199$ was more than Mucuna species NRC. Mucuna species IIHR MP5, Mucuna utilis IC25333 and Mucuna pruriens were identical in both number of bands (total of 11 bands) and banding pattern. However, a change in the intensity of band 7, 8 and 9 were observed among these samples. Mucuna hirsute showed similarity with Mucuna species IIHR MP5, Mucuna utilis IC25333 and Mucuna pruriens in the total number of bands present but differed in intensity. The major proteins corresponded to intense band numbers 2 , 7, 8 and 9 while the minor proteins were medium intensity bands 1, 3, 6 and 11 followed by very light intensity bands corresponding to band number 4, 5 and 10 .

The electrophoretic protein band pattern during germination of Mucuna pruriens is shown in Figure 2(b). Electrophoretic analysis of proteins revealed the presence of total 11 bands in the soaked seeds of Mucuna. After 24 hrs of germination, there are total 12 protein bands and intensity of the band 9 was increasing and was maximum at $48 \mathrm{hrs}$ of germination. The intensity gradually decreased there onwards till 120 hrs of germination. The intensity of the band 9 increased again on 144 hrs of germination. Similar results were observed for band 7 . The protein band 8 disappeared during 72, 96 and 120

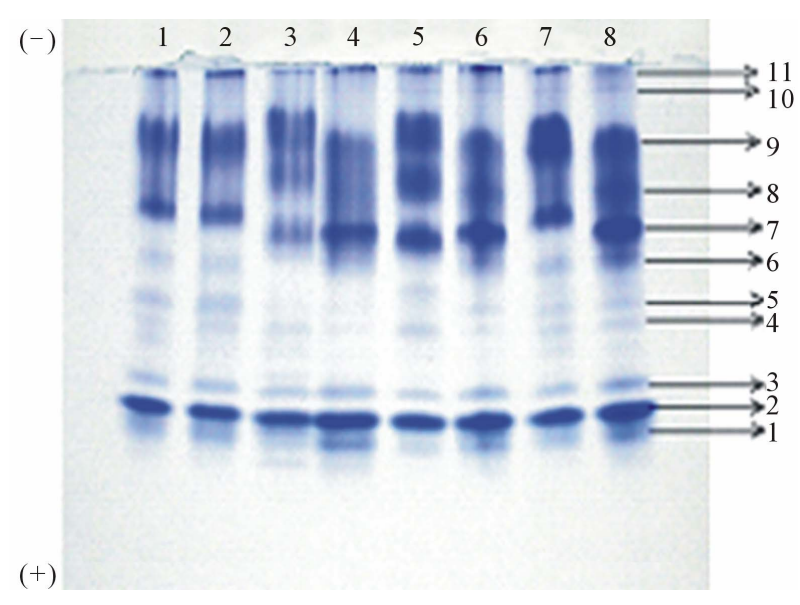

(a)

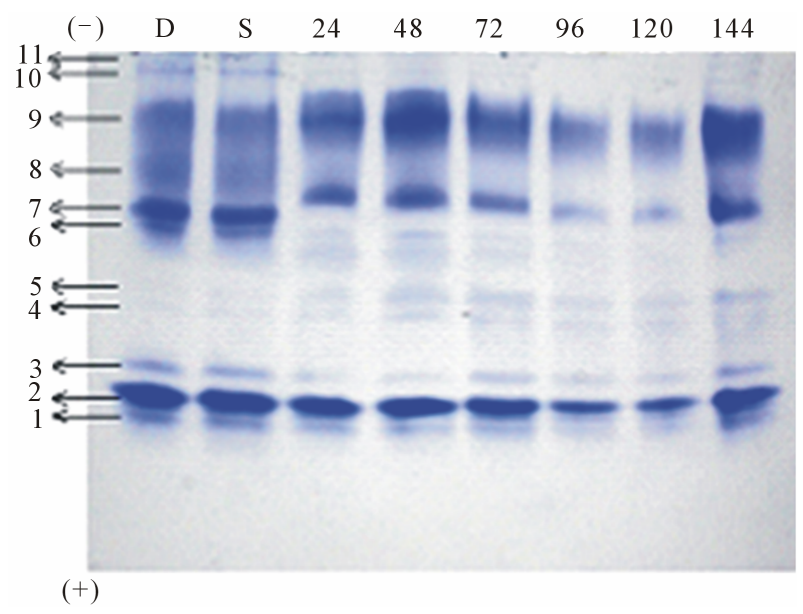

(b)

Figure 2. (a) Electrophoretic pattern of proteins isolated from 1) Mucuna hirsute; 2) Mucuna cochinensis; 3) Mucuna utilis IC25333; 4) Mucuna sps. IIHR MP5; 5) Mucuna pruriens MP7; 6) Mucuna cochinensis MP9; 7) Mucuna sps. NRC; 8) Mucuna pruriens; (b) Electrophoretic pattern of Proteins during germination of seeds of Mucuna pruriens: D: dry, S: soaked, 24 hrs, 48 hrs, 72 hrs, 96 hrs, 120 hrs and 144 hrs of germination. 
hrs of germination and reappeared on 144 hrs of germination. The intensity of the minor bands increased on germination. In addition to band 6 new bands appeared after 72 hrs of germination and disappeared there onwards. The intensity of band 10 and 11 gradually decreased up to $48 \mathrm{hrs}$ of germination and disappeared up to $120 \mathrm{hrs}$ of germination. These bands were again expressed at 144 hrs of germination. The intensity of the bands 4 and 5 increased gradually throughout the germination. Electrophoretic protein profiles of different accessions of the same subspecies showed identical or similar patterns, confirming the stability of seed storage proteins within these subspecies. However, considerable variation of protein patterns was observed among the seeds of different varieties of Mucuna pruriens, Mucuna cochinensis and Mucuna hirsute. This could be correlated to different geographical origins.

The seeds of $M$. pruriens and M. utilis IC25333 showed higher amount of proteins, trypsin inhibitory activity. $M$. pruriens is one of the major legume seed commonly available and it was chosen for further studies to analyze the effect of germination on proteins and trypsin inhibitory activity. The proteins and trypsin inhibitor profile of dry, soaked and germinated seeds of $M$. pruriens is shown in Table 3 . There is no significant decrease in TIA level was noticed up to 48 hrs of germination and gradual reduction followed by significant reduction with the increase of germination time. After 144 hrs of germination, TIA was significantly reduced (TIA was decreased by $82 \%$ ) compared to the levels in the dry seeds of Mucuna pruriens. The results obtained in this study agree with those reported for kidney bean [27], lima bean [28], Mung bean [29], lentil [30-32], pigeon bean [33], faba bean and kidney bean [34]. Electrophoretic analysis of trypsin inhibitors during germination of Mucuna pruriens are shown in Figures 1(c) and (d). It is observed the gradual decrease in the intensity of the trypsin isoinhibitor bands up to 4th day of germination and steep decrease in the intensity of the bands thereafter.

Soluble proteins are the physiologically active fractions which constitute the major bulk of enzymes involved in plant metabolism. During germination and plant development, specific metabolic changes have been observed by many investigators. The analysis of zymogram of protein banding pattern revealed the variation in the protein pattern. This result suggests the requirement of these for the development of the plant. The protein content also increased at $72 \mathrm{hrs}$ of germination and decreased thereafter. Analyses of protein banding pattern revealed the wide variation in banding pattern. The intensity of some of the major protein bands gradually decreased and few bands were disappeared followed by
Table 3. Proteins and trypsin inhibitor profile of dry, soaked and germinated seeds of Mucuna pruriens.

\begin{tabular}{ccc}
\hline Germination time & $\begin{array}{c}\text { Total protein } \\
\text { (mg/gm) }\end{array}$ & $\begin{array}{c}\text { TIA } \\
\text { (TIU/mg) }\end{array}$ \\
\hline Dry seeds & 246 & 14.81 \\
Soaked seeds & 251 & 14.81 \\
24 hrs & 253 & 13.56 \\
48 hrs & 260 & 12.69 \\
72 hrs & 276 & 11.55 \\
96 hrs & 219 & 8.16 \\
120 hrs & 124 & 2.85 \\
144 hrs & 161 & 2.62 \\
\hline
\end{tabular}

appearance of small molecular weight new protein bands during the germination. The electrophoretic studies showed that high molecular weight polypeptide bands disappeared with the appearance of new low molecular weight polypeptide bands in the endosperm proteins of the germinating seeds.

\section{Conclusion}

The protein profile of Mucuna germplasms suggests that mature Mucuna bean seeds can be used as food source and that the bean merits wider use by tribals of Karnataka and other parts of India. The high protein content in the seeds of Mucuna indicated that seeds are good source of proteins, if the seeds are properly processed. The presence of trypsin inhibitors as anti-nutritional factors identified in the current study should pose a problem in human consumption if the beans are not properly processed. Germination is one such seed processing method and this method can be used to process Mucuna beans before consumption. However, the presence pharmacologically active compound L-DOPA (L-3,4-dihdroxy phenylalanine) is potentially toxic if large amounts are ingested.

\section{Acknowledgements}

The author wish to thank UGC, SWRO, Bangalore, Karnataka, India for financial assistance, Prof. M. R. Doreswamy, Founder Chairman, PES Group of Institutions, Bangalore, Prof. D. Jawahar, CEO, PES Group of Institutions, Bangalore and Dr. K. N. B. Murthy, Principal, PES Institute of Technology, Bangalore for providing research facility to carry out this research work. The author also wishes to thank $I I H R$, Bangalore, for providing few varieties of seeds of Mucuna and people who are 
directly or indirectly involved in the collection of $M u$ cuna seeds from different parts of Karnataka as well as Tamilnadu and Kerala.

\section{REFERENCES}

[1] O. Malomo, O. A. B. Ogunmoyela and S. O. Oluwajoba, "Effect of Sprouting on Trypsin Inhibitor of Cowpea ( $\mathrm{Vi}$ gna unguiculata)," Journal of Toxicology and Environmental Health Sciences, Vol. 3, No. 5, 2011, pp. 139-141.

[2] E. Lorensen, R. Prevosto and K. Wilson, “The Appearance of New Active Forms of Trypsin Inhibitor in Germinating Mung Bean (Vigna radiata) Seeds,” Plant Physiology, Vol. 68, No. 1, 1981, pp. 88-92. doi:10.1104/pp.68.1.88

[3] M. L. Kakade and R. J. Evans, "Effect of Soaking and Germinating on the Nutritive Value of Navy Beans," Journal of Food Sciences, Vol. 31, No. 5, 1966, pp. 781786. doi:10.1111/j.1365-2621.1966.tb01941.x

[4] R. P. Bates, F. W. Knapp and P. E. Araujo, "Protein Quality of Green Mature, Dry Growth Promoting Quality of Dietary Protein,” Journal of Food Science, Vol. 42, No. 1, 1977, pp. 271-272.

[5] G. Subbulakshmi, G. K. Kumar and L. V. Venkataraman, "Effect of Germination on the Carbohydrates, Proteins, Trypsin Inhibitor, Amylase Inhibitor and Haemagglutinin in Horse Gram and Moth Bean,” Nutrition Report International, Vol. 13, No. 1, 1976, pp. 19-24.

[6] K. O. Adebowale and O. S. Lawal, "Functional Properties and Retrogradation Behavior of Native and Chemically Modified Starch of Mucuna Bean (Mucuna pruriens)," Journal of Science of Food and Agriculture, Vol. 83, No. 15, 2003, pp. 1541-1546. doi:10.1002/jsfa.1569

[7] N. Rajaram and K. Janardhanan, "The Biochemical Composition and Nutritional Potential of the Tribal Pulse Mucuna gigantea Wild DC," Plant Foods for Human Nutrition, Vol. 41, No. 1, 1991, pp. 45-52. doi:10.1007/BF02196381

[8] R. M. Josephine and K. Janardhanan, "Studies on Chemical Composition and Antinutritional Factors in Three Germplasm Seed Materials of the Tribal Pulse Mucuna pruriens (L.) DC,” Food Chemistry, Vol. 43, No. 1, 1992, pp. 13-18. doi:10.1016/0308-8146(92)90235-T

[9] I. E. Liener and M. L. Kakade, "Proteinase Inhibitors,” In: I. E. Liener, Ed., The Toxic Constituents of Plant Food Stuffs, 2nd Edition, Academy Press, New York, 1980, pp. 7-71.

[10] N. R. Reddy, M. D. Pierson, S. K. Sathe and D. K. Salunkhe, "Dry Bean Tannin: A Review of Nutritional Implication," Journal of the American Oil Chemists Society, Vol. 62, No. 3, 1985, pp. 451-549. doi:10.1007/BF02542329

[11] K. C. Chang and R. L. Harrold, "Changes in Selected Biochemical Components, in Vitro Protein Digestibility and Amino Acids in Two Bean Cultivars during Germination,” Journal of Food Science, Vol. 53, No. 3, 1988, pp. 783-787. doi:10.1111/j.1365-2621.1988.tb08955.x
[12] C. Vidal-Valverde and J. Frias, "Changes in Carbohydrates during Germination of Lentils," Zeitschrift fur Lebensmittel Untersuchung und Forschung, Vol. 194, No. 5, 1992, pp. 461-464. doi:10.1007/BF01197729

[13] L. R. Wetter, "Some Properties of Lipase Present in Germinating Rape Seeds," Journal of the American Oil Chemists Society, Vol. 34, No. 2, 1957, pp. 66-69. doi:10.1007/BF02638019

[14] O. H. Lowry, N. J. Rosebrough, A. L. Farr and R. J. Randall, "Protein Measurement with the Folin Phenol Reagent,” Journal of Biological Chemistry, Vol. 193, No. 1, 1951, pp. 265-275.

[15] M. L. Kakade, N. R. Simons and I. E. Liener, "The Evaluation of Natural vs. Synthetic Substrates for Measuring the Antitryptic Activity of Soybean Samples,” Cereal Chemistry, Vol. 46, No. 5, 1969, pp. 518-526.

[16] M. L. Kakade, N. R. Simons and I. E. Liener, “The Molecular Weight of Bowman and Birk Soybean Protease Inhibitor,” Biochimica et Biophysica Acta, Vol. 200, No. 1, 1969, pp. 168-169.

[17] B. J. Davis and L. Ornstein, "Disc Electrophoresis 1. Background and Theory," Annals of the New York Academy of Sciences, Vol. 121, 1964, pp. 321-349.

[18] F. Moreira, "Visualisation of Proteinase Inhibitors in SDS Poyacrylamide Gels,” Analytical Biochemistry, Vol. 84, No. 1, 1978, pp. 296-303. doi:10.1016/0003-2697(78)90512-2

[19] G. E. A. Costa, K. S. Queiroz-Monici, S. M. P. M. Reis and A. C. Oliveira, "Chemical Composition, Dietary Fibre and Resistant Starch Contents of Raw and Cooked Pea, Common Bean, Chickpea and Lentil Legumes," Journal of Food Chemistry, Vol. 94, No. 3, 2006, pp. 327-330. doi:10.1016/j.foodchem.2004.11.020

[20] S. Kumar, G. K. Singh, R. Kumar, N. K. Bhatia and C. P. Awasthi, "Variation in Quality Traits of Pigeon Pea (Cajanus cajan L. Mill sp.) Varieties,” Journal of Food Science and Technology, Vol. 28, 1991, pp. 174-178.

[21] M. A. Mwasaru, K. Muhammad, J. Bakar, B. Yaakob and C. Man, "Effects of Isolation Technique and Conditions on the Extractability, Physicochemical and Functional Properties of Pigeonpea (Cajanus cajan) and Cowpea (Vigna unguiculata) Protein Isolates. I. Physicochemical Properties," Food Chemistry, Vol. 67, No. 4, 1999, pp. 435-444. doi:10.1016/S0308-8146(99)00150-8

[22] S. K. Sathe and D. K. Salunkhe, “Technology of Removal of Unwanted Components of Dry Beans,” CRC Critical Reviews in Food Science and Nutrition, Vol. 21, No. 3, 1984, pp. 263-287. doi:10.1080/10408398409527402

[23] M. Pugalenthi, V. Vadivel and P. Siddhuraju, “Alternative Food/Feed Perspectives of an Underutilized Legume Mucuna pruriens var. Utilis-A Review," Plant Foods for Human Nutrition, Vol. 60, No. 4, 2005, pp. 201-218. doi:10.1007/s11130-005-8620-4

[24] J. B. Mugendi, E. N. M. Njagi, E. N. Kuria, M. A. Mwasaru, J. G. Mureithi and Z. Apostolides, "Effects of Processing Technique on the Nutritional Composition and Anti-Nutrient Content of Mucuna Bean (Mucuna pruriens L.)," African Journal of Food Science, Vol. 4, No. 4, 
2010, pp. 156-166.

[25] C. Smith, W. V. Megen, L. Twaalfhoven and C. Hitchcock, "The Determination of Trypsin Inhibitor Levels in Foodstuffs," Journal of the Science of Food and Agriculture, Vol. 31, No. 4, 1980, pp. 321-350. doi:10.1002/jsfa.2740310403

[26] H. P. S. Makkar, K. Becker, H. Abel and E. Pawelzik, "Nutrient Contents, Rumen Protein Degradability and Antinutritional Factors in Some Colour and White-Flowering Cultivars of Vicia faba Beans," Journal of the Science of Food and Agriculture, Vol. 75, No. 4, 1997, pp. 511-520.

doi:10.1002/(SICI)1097-0010(199712)75:4<511::AID-JS FA907>3.0.CO;2-M

[27] S. K. Sathe, S. S. Desphande, N. R. Reddy, D. E. Goll and D. K. Salunkhe, "Effect of Germination on Proteins, Raffinose Oligosaccharides and Antinutritional Factors in Great Northern Beans (Phaseolus vulgaris L)," Journal of Food Science, Vol. 48, No. 6, 1983, pp. 1796-1800. doi:10.1111/j.1365-2621.1983.tb05087.x

[28] A. D. Ologhobo and B. L. Fetuga, "Trypsin Inhibitory Activity in Some Lima Bean Varieties as Affected, by Different Processing Method," Nutrition Reports International, Vol. 27, No. 1, 1983, pp. 41-49.

[29] A. E. Mubarak, "Nutritional Composition and Antinutritional Factors of Mung Bean Seeds (Phaseolus aureus) as Affected by Some Home Traditional Processes,” Food
Chemistry, Vol. 89, No. 4, 2005, pp. 489-495. doi:10.1016/j.foodchem.2004.01.007

[30] A. R. El-Mandy, Y. G. Moharam and O. R. AbouSamaha, "Influence of Germination on Nutritional Quality of Lentil Seeds," Zeitschrift für Lebensmittel-Untersuchung und Forschung, Vol. 181, No. 4, 1983, pp. 318320.

[31] J. H. Frias, C. Diaz-Pollan, C. L. Hedley and C. VidalValverde, "Evolution of Trypsin Inhibitor Activity during Germination of Lentils," Journal of Agricultural and Food Chemistry, Vol. 43, No. 8, 1995, pp. 2231-2234. doi:10.1021/jf00056a049

[32] C. Vidal-Valverde, J. H. Frias, I. Estrella, M. J. Gorospe, R. Ruiz and J. Bacon, "Effect of Processing on Some Antinutritional Factors of Lentils," Journal of Agricultural and Food Chemistry, Vol. 42, No. 10, 1994, pp. 2291-2295. doi:10.1021/jf00046a039

[33] A. Torres, J. Frias, M. Granito and C. Vidal-Valverde, "Germinated Cajanus cajan Seeds as Ingredient in Pasta Products: Chemical and Biological and Sensory Evaluation," Food Chemistry, Vol. 101, No. 1, 2007, pp. 202211. doi:10.1016/j.foodchem.2006.01.018

[34] R. Alonso, E. A. Aguirre and F. Marzo, "Effect of Extrusion and Traditional Processing Methods, on Antinutritionals and in Vitro Digestibility of Protein and Starch in Faba and Kidney Beans," Food Chemistry, Vol. 68, No. 2, 2000, pp. 159-165. doi:10.1016/S0308-8146(99)00169-7 